\title{
Characterization of a Novel Potyvirus Isolated from Maize in Israel
}

\author{
D. L. Seifers, R. Salomon, V. Marie-Jeanne, B. Alliot, P. Signoret, \\ S. Haber, A. Loboda, W. Ens, Y.-M. She, and K. G. Standing
}

\begin{abstract}
First author: Kansas State University, Agricultural Research Center, Hays 67601-9228; second author: Volcani Center, Bet-Dagan, Israel; third to fifth authors: Ecole Nationale Supérieure Agronomique de Montpellier-Institut National de la Recherche Agronomique, 2 Place Pierre Viala, 34 060, Montpellier, France; sixth author: Cereal Research Centre, Agriculture \& Agri-Food Canada, 195 Dafoe Road, Winnipeg, Manitoba, Canada; and seventh to tenth authors: Department of Physics, University of Manitoba, Winnipeg, Manitoba, R3T 2N2, Canada. Accepted for publication 7 February 2000.
\end{abstract}

\begin{abstract}
Seifers, D. L., Salomon, R., Marie-Jeanne, V., Alliot, B., Signoret, P., Haber, S., Loboda, A., Ens, W., She, Y.-M., and Standing, K. G. 2000. Characterization of a novel potyvirus isolated from maize in Israel. Phytopathology 90:505-513.

A potyvirus (proposed name of Zea mosaic virus [ZeMV]) isolated from maize in Israel was analyzed by serology, sodium dodecyl sulfatepolyacrylamide gel electrophoresis (SDS-PAGE) of capsid proteins, symptomatology, and sequencing. Parts of the nuclear inclusion $b$, coat protein, and ' 3 ' regions were sequenced; the amino acid sequence of ZeMV capsid was determined by time-of-flight mass spectrometry (TOFMS). The results of these analyses were compared with those of similar analyses of the following potyviruses: Maize dwarf mosaic virus (MDMV), Sugarcane
\end{abstract}

ABSTRACT mosaic virus strain MDB (SCMV-MDB), Johnsongrass mosaic virus (JGMV), Sorghum mosaic virus (SrMV), and an isolate of MDMV from Israel. Indirect enzyme-linked immunosorbent assay using ZeMV antiserum detected only ZeMV, and reciprocal tests using MDMV, JGMV, or SrMV antisera failed to detect ZeMV. ZeMV cross-reacted weakly when SCMV-MDB antiserum was used. The mass of ZeMV capsid was determined to be $36,810 \mathrm{Da}$ by SDS-PAGE and $34,216 \mathrm{Da}$ by TOFMS. The ZeMV systemically infected johnsongrass (Sorghum halepense), but did not infect oat (Avena sativa), pearl millet (Pennisetum glaucum), barley (Hordeum vulgare), or rye (Secale cereale). Necrosis was caused in 19 sorghum lines by SrMV, in 15 by ZeMV, in 14 by MDMV, and in 5 by JGMV and SCMV-MDB. The nucleic acid and amino acid sequences of ZeMV clearly showed that it is not a strain of JGMV, MDMV, SCMV, or SrMV.
The potyvirus group is the largest and most important group of plant viruses (28). Its members share similar morphology, particle structure, host range, and modes of transmission (18). Four distinct potyviruses infect maize and sorghum: Maize dwarf mosaic virus (MDMV), Sugarcane mosaic virus (SCMV), Johnsongrass mosaic virus (JGMV), and Sorghum mosaic virus (SrMV) $(47,48)$ forming a subgroup in the genus Potyvirus (7). MDMV and SCMV occur throughout the world (34), whereas JGMV has been reported in Australia and the United States (46), and SrMV in the United States $(1,21,46,52)$.

In Israel, MDMV has been isolated from maize and sorghum $(4,8,20)$. Another potyvirus isolated from maize in Israel did not react to MDMV antiserum and was more aggressive on sorghum than on maize. It was designated, tentatively, as a JGMV isolate based on coat protein mobility in electrophoresis (8). We present here results of serological, symptomalogical, and biological analyses and molecular sequence information demonstrating that this virus (proposed here as Zea mosaic virus [ZeMV]) is sufficiently different from MDMV, SCMV, JGMV, and SrMV to be considered a distinct potyvirus species.

\section{MATERIALS AND METHODS}

Virus source and maintenance. Isolates from Kansas of MDMV, SCMV-MDB (formerly MDMV-B), and JGMV were obtained from sorghum (Sorghum bicolor (L.) Moench) at Hays, KS. An isolate of SrMV was obtained from the American Type Culture Collection (PV 323) (3). Israeli isolates of MDMV and ZeMV were obtained from R. Salomon. All viruses were propagated in 'GATE

Corresponding author: D. L. Seifers; E-mail address: dseifers@ oznet.ksu.edu

Publication no. P-2000-0322-02R

(C) 2000 The American Phytopathological Society
76' sorghum by inoculating mechanically with $1: 10$ (wt/vol) extracts from source plants as described previously (10). Inoculated plants were held in separate growth chambers at $25^{\circ} \mathrm{C}$ with $12 \mathrm{~h}$ of illumination $\left(500 \mu \mathrm{E} \mathrm{s}^{-1} \mathrm{~m}^{-2}\right)$ per day. At 14 days postinoculation, infected tissue was harvested and frozen at $-80^{\circ} \mathrm{C}$ for later use. In France, ZeMV was propagated mechanically and used for nucleic acid sequencing experiments and, in Israel, ZeMV was maintained by aphid transfer.

Antiserum. Antiserum was prepared as previously described (41) except that TiterMax (Vaxcel, Inc., Norcross, GA) was substituted for Freund's incomplete adjuvant. Purified ZeMV $(300 \mu \mathrm{g})$ was mixed (1:1, vol/vol) with adjuvant and injected twice, with 1 week elapsing between the injections. The immunoglobulin $\mathrm{G}(\mathrm{IgG})$ fraction was obtained from serum by ammonium sulfate precipitation as previously described (41). At $1 \mathrm{mg} / \mathrm{ml}$, the $\mathrm{IgG}$ fractions (against a 1:30 [wt/vol] dilution of the sorghum at 14 days postinoculation) had indirect enzyme-linked immunosorbent assay (ELISA) values of $0.219,0.035,0.057,0.034,0.026$, and 0.011 for extracts of sorghum (14 days postinoculation) infected by ZeMV, MDMV, SCMVMDB, JGMV, SrMV, and healthy sorghum, respectively. Antisera to MDMV and JGMV were prepared as described previously (41). The SCMV-MDB antiserum was obtained from R. Louie (USDA/ ARS, Wooster, OH) and that of SrMV was from K. Scholtoff (Texas A\&M University, College Station, TX).

Indirect ELISA. The procedure used was as previously described (43). ZeMV IgG was used at $1 \mu \mathrm{g} / \mathrm{ml}$, and all plant tissue was sampled at a 1:30 (wt/vol) dilution. Antisera of MDMV, SrMV, and SCMV-MDB were used at 1,1 , and $2.5 \mu \mathrm{g} / \mathrm{ml}$, respectively. Goat antirabbit antibody/alkaline phosphatase conjugate was used at 1:3,000, vol/vol (catalog no. 4050-04; Fisher Scientific, Norcross, GA).

Minipurification, sodium dodecyl sulfate-polyacrylamide gel electrophoresis (SDS-PAGE), estimation of relative molecular masses, and western blotting of proteins. ZeMV proteins were extracted and minipurified following the procedure of Lane (25) 
as described elsewhere (43). SDS-PAGE was done as previously described (23) using electrophoresis and gel-staining conditions as previously described (43). Relative molecular masses were calculated using a densitometer to determine electrophoretic mobility (42) by comparison with protein standards (ProSieve protein markers; FMC BioProducts, Rockland, ME).

Electrophoretic analyses were conducted a minimum of two times using extracts from different symptomatic plants. Samples of healthy plant tissue samples were treated and tested identically.

Plant extractions and separations by SDS-PAGE and transfer of proteins onto nitrocellulose membranes for western blottings were done as previously described (42). Alkaline phosphatase goat antirabbit antibody conjugate (1:3,000 dilution; Fisher Scientific) was used for immunoblotting as described by Bollig and Edelstein (9).

Infectivity and host range assays. Plants (two-leaf stage) were inoculated mechanically as described above. Inoculated plants were held in a growth chamber at $24^{\circ} \mathrm{C}$ for 2 weeks using the light conditions described above.

'Westford' barley (Hordeum vulgare L.), 'Lodi' oat (Avena sativa L.), 'C-130' pearl millet (Pennisetum glaucum (L.) R. Br.), 'Mayton' rye (Secale cereale L.), 'GATE 76' sorghum, and johnsongrass (Sorghum halepense (L.) Pers.) were planted into soil-filled plant cells (Stuewe \& Sons, Corvallis, OR). Plants were inoculated mechanically at the two- to three-leaf stage with extracts prepared from sorghum systemically infected with the appropriate virus. Following inoculation, the plants were held in a growth chamber, rated for symptoms 28 days later, and then tested by back-inoculation (using the youngest leaf from the test plant) to sorghum. Following preparation of ZeMV antiserum, infection was confirmed by ELISA. Symptomatic plants were tested individually, and nonsymptomatic plants were bulked. Controls consisted of ZeMVinfected and mock-inoculated sorghum. Barley seed was obtained from Townsend Seed Inc. (Townsend, MT); oat, millet, rye, and sorghum from Kansas State University (Agricultural Research Center, Hays); and johnsongrass from Valley Seed Service (Fresno, CA).

Virulence of ZeMV was compared with that of MDMV, SCMVMDB, JGMV, and SrMV by inoculating the sorghum lines KS 5A, KS 6R, KS 7R, KS 19, KS 34A, KS 35A, KS 36A, KS 37A, KS 38A, KS 39A, KS 41R, KS 49R, KS 50A, KS 53R, KS 57A, KS 79A, KS 80A, KS 83A, and KS 90R with these viruses.

Virus purification for antibody production, time-of-flight mass spectrometry (TOFMS), RNA extraction, and nucleic acid sequencing. ZeMV was purified for production of antibodies and TOFMS as previously described for Wheat streak mosaic virus (43). For RNA extraction and sequencing, freshly harvested symptomatic leaves of sorghum ('Rosus') were ground ( $2 \mathrm{ml}$ of tissue per g) in a Waring blender (Waring Products, New Hartford, CT) in borate buffer (obtained by mixing $0.2 \mathrm{M}$ boric acid and $0.1 \mathrm{M}$ borax [until pH reaches 8], 0.01 M EDTA, and 0.3\% $\beta$-mercaptoethanol), and the mixture was made to $30 \%$ ( $\mathrm{vol} / \mathrm{vol}$ ) with chloroform and mixed. The mixture was centrifuged at $8,000 \times g$ for $10 \mathrm{~min}$ at $4^{\circ} \mathrm{C}$, and the supernatant was collected and retained on ice. The pellet and the organic phase were remixed with the same solution, but without chloroform, and centrifuged as described above. The supernatant from the second centrifugation was collected and mixed with the first supernatant, and the combined supernatant was made to $6 \%(\mathrm{wt} / \mathrm{vol})$ with polyethylene glycol (molecular weight 6,000$)$ and $2 \% \mathrm{NaCl}$ and stirred for $1 \mathrm{~h}$ at $4{ }^{\circ} \mathrm{C}$. The virus was pelleted from solution by centrifuging at $10,000 \times g$ for $10 \mathrm{~min}$ at $4^{\circ} \mathrm{C}$, and the supernatant was discarded. The pellet was resuspended in Sörensen buffer (obtained by adding a 0.06-M-disodium phosphate solution to a $0.06-\mathrm{M}$-monopotassium phosphate solution until $\mathrm{pH}$ was 7.5 and then diluting the resulting solution to $0.02 \mathrm{M}$ ) containing $1 \%$ Triton X-100 and then centrifuged at $10,000 \times$ g for 10 min at $4{ }^{\circ} \mathrm{C}$; the pellet was discarded. The resuspended virus was then centrifuged at $90,000 \times \mathrm{g}$ for $3 \mathrm{~h}$ at $4{ }^{\circ} \mathrm{C}$ through a cushion of $20 \%(\mathrm{wt} / \mathrm{vol})$ saccharose. The pellet was resuspended in Sörensen buffer and centrifuged on a $\mathrm{CsSO}_{4}(360 \mathrm{mg} / \mathrm{ml})$ gradient generated at $120,000 \times \mathrm{g}$ for $16 \mathrm{~h}$ at $15^{\circ} \mathrm{C}$. The virus zone was removed using a needle attached to a syringe, diluted with Sörensen buffer, and centrifuged at $170,000 \times g$ for $2.5 \mathrm{~h}$ at $4^{\circ} \mathrm{C}$. The pellet was resuspended in Sörensen buffer and used for extraction of RNA. The viral RNA was extracted using the proteinase K/SDS/phenol method of Chachulska et al. (10).

cDNA synthesis, amplification, cloning, and sequencing. Oligonucleotides were designed based on conserved regions of poaceaeinfecting potyviruses or by previous sequencing results and were fully complementary to the sequence of the Israeli isolate (Table 1). cDNA was synthesized using Moloney murine leukemia virus (MMLV) $(200 \mu / \mu \mathrm{l})$ reverse transcriptase from Gibco BRL (CergyPontoise, France) and buffers provided by the manufacturer in a final volume of $20 \mu \mathrm{l}$. In the first step, $1 \mu \mathrm{g}$ of viral RNA, $300 \mathrm{ng}$ of reverse primer, and water to $12.5 \mu \mathrm{l}$ were mixed, incubated at $70^{\circ} \mathrm{C}$ for $10 \mathrm{~min}$, and immediately chilled on ice. After that, $4 \mu \mathrm{l}$ of $5 \times$ first-strand buffer, $2 \mu \mathrm{l}$ of $100 \mathrm{mM}$ dithiothreitol, $1 \mu \mathrm{l}$ of dNTPs (10 mM each), and $0.5 \mu \mathrm{l}$ of MMLV were added, and the mixture was incubated for $1 \mathrm{~h}$ at $37^{\circ} \mathrm{C}$. Temperature cycling conditions of the primer pairs were as follows: Oligo 1-Oligo $2=1$ cycle of $3 \mathrm{~min}$ at $95^{\circ} \mathrm{C} ; 30$ cycles of $50 \mathrm{~s}$ at $50^{\circ} \mathrm{C}, 50 \mathrm{~s}$ at $72^{\circ} \mathrm{C}$, and $1 \mathrm{~min}$ at $95^{\circ} \mathrm{C}$; and 1 cycle of $10 \mathrm{~min}$ at $72^{\circ} \mathrm{C}$; Oligo 1 -dTV $=1$ cycle of 3 min at $95^{\circ} \mathrm{C} ; 30$ cycles of $1 \mathrm{~min} 30 \mathrm{~s}$ at $38^{\circ} \mathrm{C}, 1 \mathrm{~min} 15 \mathrm{~s}$ at $72^{\circ} \mathrm{C}$, and $1 \mathrm{~min}$ at $95^{\circ} \mathrm{C}$; and 1 cycle of $10 \mathrm{~min}$ at $72^{\circ} \mathrm{C}$; nuclear inclusion b (NIb)-Isl $=1$ cycle of $5 \mathrm{~min}$ at $95^{\circ} \mathrm{C} ; 4$ cycles of $5 \mathrm{~min}$ at $40^{\circ} \mathrm{C}, 1 \mathrm{~min}$ at $72^{\circ} \mathrm{C}$, and $1 \mathrm{~min}$ at $95^{\circ} \mathrm{C} ; 29$ cycles of $2 \mathrm{~min}$ at $40^{\circ} \mathrm{C}$, $1 \mathrm{~min}$ at $72^{\circ} \mathrm{C}$, and $45 \mathrm{~s}$ at $95^{\circ} \mathrm{C}$; and 1 cycle of $10 \mathrm{~min}$ at $72^{\circ} \mathrm{C}$; and NIb-Rev $2=2$ cycles of $3 \mathrm{~min}$ at $95^{\circ} \mathrm{C}, 1 \mathrm{~min} 30 \mathrm{~s}$ at $57^{\circ} \mathrm{C}$, and $50 \mathrm{~s}$ at $72^{\circ} \mathrm{C} ; 29$ cycles of $1 \mathrm{~min}$ at $95^{\circ} \mathrm{C}, 1 \mathrm{~min} 30 \mathrm{~s}$ at $57^{\circ} \mathrm{C}$, and $50 \mathrm{~s}$ at $72^{\circ} \mathrm{C}$; and $1 \mathrm{cycle}$ of $8 \mathrm{~min}$ at $72^{\circ} \mathrm{C}$.

Amplification reactions were performed using Taq polymerase $(5 \mu / \mu \mathrm{l})$ from Gibco BRL using the buffers provided with the enzyme. The reaction mixture consisted of $1 \mu \mathrm{l}$ of cDNA, $50 \mathrm{pmol}$ each of reverse and forward primers, $5 \mu \mathrm{l}$ of $10 \times$ buffer, $1.5 \mu \mathrm{l}$ of $\mathrm{MgCl}_{2}(50 \mathrm{mM}), 2 \mu \mathrm{l}$ of $1 \% \mathrm{~W}-1$ (detergent in buffer kit; Gibco BRL), $1 \mu \mathrm{l}$ of dNTPs (10 mM each), $0.8 \mu \mathrm{l}$ of Taq polymerase, and $\mathrm{H}_{2} \mathrm{O}$ to $50 \mu \mathrm{l}$.

TABLE 1. Primers used for cloningy and reverse-transcriptase-polymerase chain reaction analysis

\begin{tabular}{|c|c|c|}
\hline Primers & Sequences ${ }^{\mathrm{z}}$ & Properties \\
\hline \multicolumn{3}{|c|}{ Forward primers } \\
\hline Oligo 1 & GTATGGTGCATCGAAAATGGT & Corresponds to the MVWCIENG motif of the capsid protein (CP) of Sugarcane mosaic virus strains \\
\hline $\mathrm{NIb}$ & GCYCCRTAYATWGCMGAAWCRGC & Deduced from multiple sequence alignment of $\mathrm{COOH}$-termini of $\mathrm{NIb}$ from poaceae-infecting potyviruses \\
\hline Oligo 2 & TGCTGCTGCTTTCATCTG & Corresponds to the QMKAAA motif of the CP of Maize dwarf mosaic virus (MDMV)-JIL \\
\hline dTV & $(\mathrm{dT})_{21} \mathrm{~V}$ & Complementary to the polyA tail \\
\hline Isl & GCTTCAGCCGCATCACTAAAATGG & Complementary to the Israeli isolate \\
\hline
\end{tabular}

${ }^{\mathrm{z}}$ Redundancy code $\mathrm{V}=\mathrm{C} / \mathrm{G} / \mathrm{T}, \mathrm{Y}=\mathrm{C} / \mathrm{T}, \mathrm{R}=\mathrm{A} / \mathrm{G}, \mathrm{W}=\mathrm{A} / \mathrm{T}$, and $\mathrm{M}=\mathrm{A} / \mathrm{C}$. 
First, a fragment corresponding to the amplification product between the primers Oligo 1 and Oligo 2 (Table 1) was sequenced directly. The amplification product of primers Oligo 1 and dTV was ethanol-precipitated and cloned in pGEM-T Easy (Promega, Charbonnières, France) following the instructions of the manufacturer. Three clones in the region covering Oligo 1 to the end of the genome were sequenced. The amplification product between $\mathrm{NIb}$ and Isl was purified from an agarose gel with QIAquick from (Qiagen, Courtaboeuf, France) prior to cloning in the same vector. Two independent clones were sequenced. The amplification fragment between NIb and Rev 2 was purified from an agarose gel and directly sequenced.

Nucleotide sequencing reactions were performed by Genome Express (Grenoble, France) by means of a dideoxy sequencing method using specific primers for polymerase chain reaction products or universal primers for plasmids (Table 1). Pairwise sequence comparisons between different poaceae-infecting potyviruses and Ryegrass mosaic virus (RGMV) were made using the GAP program of the Genetic Computer Group (GCG) sequence analysis software, version 10.0, from the University of Wisconsin (12). Nucleotide sequence identities and amino acid sequence similarities are reported in Table 2.

Multiple sequence alignments were obtained either with the GPC program PILEUP or with the program Clustal W (51); the alignments were inspected visually. Multiple sequence alignments produced by Clustal $\mathrm{W}$ were used as input data for reconstructing phylogenetic trees using Kimura distance and the neighbor-joining method implemented in the option draw tree of the phylogenetic tree menu of Clustal W. A bootstrap value for each internal node was calculated by performing 100 random samplings using the bootstrap option of the phylogenetic tree menu. The trees were visualized with program Treeview. Wheat spindle streak mosaic virus (WSSMV), a potyvirus, was used as the outgroup for rooting the trees. Barley stripe mosaic virus (BStMV) and RGMV, two potyviridae viruses infecting members of the family Poaceae, and Potato virus $Y$ (PVY), Lettuce mosaic virus (LMV), and Plum pox virus (PPV), three potyviruses infecting dicotyledons, were also included in the phylogenetic reconstructions. To confirm the neighbor-joining trees, the parsimony method using PAUP Search, a GCG front-end to D. Swofford's PAUP (phylogenetic analysis using parsimony) program was used. The sources of sequence data and sequence identities are presented in Table 2.

TOFMS mass determinations and amino acid sequencing. Capsid proteins (CP) of ZeMV (purified as described above) were lyophilized and sent to the University of Manitoba, where the masses and amino acid sequences were determined by TOFMS. The mass of the coat protein subunits was measured in a TOF mass spectrometer (50) in the linear mode using matrix-assisted laser desorption/ionization (MALDI) for ion production (matrix $\alpha$-cyano4-hydroxycinnamic acid) and external calibration with horse skeletal muscle myoglobin.

Masses of the fragments produced by digestion of the protein with various proteases (trypsin, Lys-C, Arg-C, and Glu-C) were measured in a hybrid quadrupole/TOF mass spectrometer (11) using a

TABLE 2. Percent nucleotide sequence identity of the 3' noncoding region (above diagonal) and amino acid (below diagonal) sequence similarity either on the whole coat protein (upper number in each box) or restricted to the core of the capsid protein (lower number in each box) of the Israeli virus (Zea mosaic virus $[\mathrm{ZeMV}])$ compared to other viruses ${ }^{\mathrm{z}}$

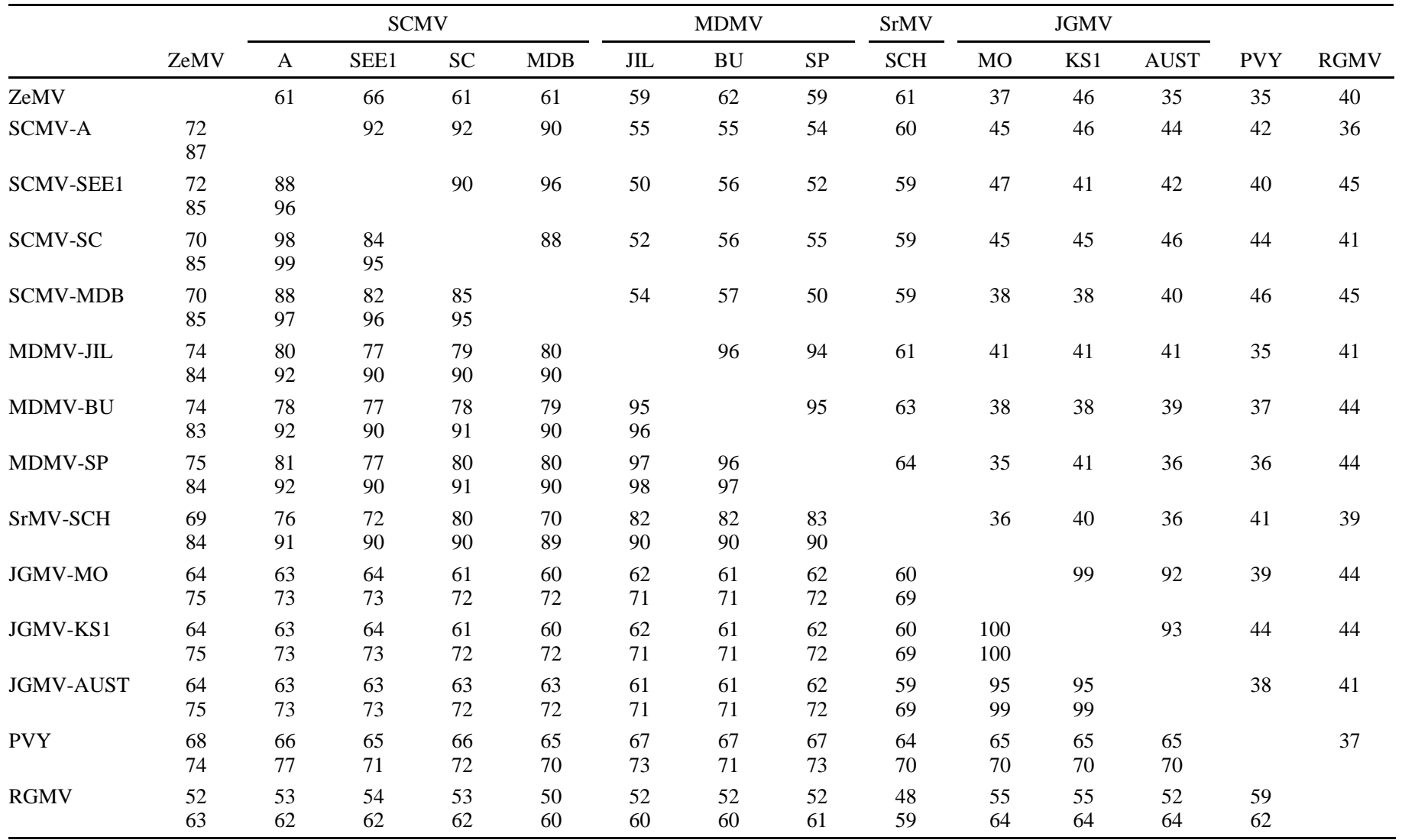

${ }^{\mathrm{z}}$ Virus, GenBank accession number, and reference: Maize dwarf mosaic virus (MDMV)-SP, not registered (2); MDMV-JIL, U07216 (J. M. Jilka and J. M. Clark, unpublished data); MDMV-BU, AJ001691 (22); Sugarcane mosaic virus (SCMV)-CHI, S77088 (39); SCMV-MDB, D00949 (14); SCMV-SC, D00948 (14); SCMV-SEE1, X98165 (32); SCMV-SEE2, X98166 (32); SCMV-BOR, X98167 (32); SCMV-BOE, X98168 (32); SCMV-HOE, X98169, (32); SCMV-A, U57354 (55); SCMV-B, U57355 (55); SCMV-D, U57356 (55); SCMV-E, U57357 (55); Johnsongrass mosaic virus (JGMV)-KS1, U07218 (J. M. Jilka and J. M. Clark, unpublished data); JGMV-MO, U07217 (J. M. Jilka and J. M. Clark, unpublished data); JGMV-AUST, Z26920 (17); Sorghum mosaic virus (SrMV)-SCH, U07219 (J. M. Jilka and J. M. Clark, unpublished data); SrMV-SCH-TX, U57358 (55); SrMV-SCI, U57359 (55); SrMV-SCM, U57360 (55); Potato virus Y (PVY), D00441 (37); Lettuce mosaic virus (LMV)-E, X97705 (36); Plum pox virus (PPV), M21847 (24); Ryegrass mosaic virus (RGMV), Y09854 (40); Brome streak mosaic virus (BrSMV), Z48506 (16); and Wheat spindle streak mosaic virus (WSSMV), X73883 (49). 
MALDI source for ion production (matrix $\alpha$-cyano-4-hydroxycinnamic acid) and also in an electrospray/TOF mass spectrometer (53). Comparison with the predicted masses of the proteolytic fragments as calculated from the nucleic acid sequence (peptide mass fingerprinting) then yielded the amino acid sequence. Most of the sequences (approximately 93\%) also were checked by tandem mass spectrometry (MS/MS) measurements (11) in the same spectrometer.

\section{RESULTS}

ELISA. Uniformly negative results were obtained when MDMV or JGMV antisera were used in ELISA with ZeMV antigen, but weak reactions were observed when SCMV-MDB antiserum was used (9.4 times greater than the healthy control versus 15.1 times for the positive control) (data not shown). ZeMV was compared further with MDMV, SCMV-MDB, and SrMV by inoculating johnsongrass, oat, pearl millet, barley, rye, and sorghum with the four viruses.

ZeMV infected only johnsongrass and the sorghum control. Only two johnsongrass plants out of 43 inoculated (in three experiments) were infected by ZeMV, indicating difficulty in infecting this species. MDMV infected johnsongrass and pearl millet; SCMV-MDB infected only pearl millet; JGMV infected johnsongrass, oat, and pearl millet; and SrMV did not infect any of these species.

Sorghum was inoculated using extracts from systemically infected johnsongrass. When these ZeMV-infected plants were tested by ELISA against various antiserum, ZeMV again showed a slight response to two different sources of SCMV-MDB antisera after passage through johnsongrass (data not shown).

Antiserum prepared using CsCl-purified ZeMV was tested by ELISA against various viruses (Table 3). The ZeMV antiserum did not react against either the MDMV isolate or the JGMV-KS isolate. However, some reactivity to SCMV-MDB was observed at all dilutions. Antiserum against SCMV-MDB reacted weakly to ZeMV. At the 1:400 dilution, the reaction of the ZeMV antiserum to SCMV-MDB was 3.1 times greater than the healthy value, whereas the ZeMV positive control was 7.6 times larger. The ELISA value of the SCMV-MDB antiserum against ZeMV was 4.9 times larger than the healthy control, while the positive control was 13.5 times larger. As expected, the ZeMV IgG probe reacted to SCMV-MDB in western blotting experiments (data not shown). This reactivity may reside in the first eight amino acids (Fig. 1, 51 to 56) of the $\mathrm{N}$-terminal of ZeMV. With the exception of the amino acid at location 54, which is A in MDMV-MDB and V in ZeMV, the sequence of both viruses is identical and may constitute sufficient conformational identity to constitute a shared epitope resulting in the reactions presented in Table 3 .

Capsid mass determinations. In SDS-PAGE, when compared with MDMV, SCMV-MDB, JGMV, and SrMV, the capsid of ZeMV migrated to a position between those of MDMV and SCMV-MDB capsids (data not shown). The relative molecular mass of ZeMV in three SDS-PAGE trials was 36,885, 36,548, and 36,895 Da, giving an average of $36,776 \mathrm{Da}$. When aliquots of the same material were analyzed by TOFMS, values of $34,222,34,210$, and $34,210 \mathrm{Da}$ were determined, giving an average of $34,214 \mathrm{Da}$. The value predicted by SDS-PAGE is about $7 \%$ greater than the value predicted by TOFMS. The mass determined by TOFMS is about $6 \%$ greater than that predicted by the nucleic acid sequence (34,152 Da), because TOFMS analysis demonstrated that the N-terminal of ZeMV capsid is acetylated, accounting for an additional $42 \mathrm{Da}$. Thus, the value measured by TOFMS differs by $20 \mathrm{Da}$, just outside the estimated error of approximately $0.05 \%$.

Host effects. When ZeMV, MDMV, SCMV-MDB, JGMV, and SrMV were inoculated to 19 sorghum lines from Kansas, each virus infected all lines. Necrosis was caused in 19 lines by SrMV, in 15 lines by ZeMV, in 14 lines by MDMV, and in 5 lines by SCMVMDB and JGMV (data not shown). Phenotypic responses of certain sorghum lines to ZeMV differed from responses to the other viruses (Table 4). ZeMV induced necrosis in KS 6R, differentiating it from MDMV and JGMV, but not from SCMV-MDB and SrMV. It induced necrosis in KS 35A and KS 36R, which separated it from SCMV-MDB and JGMV. Infection of KS 53R by ZeMV resulted in only mosaic symptoms, which differed from SrMV, but not from the other viruses.

Nucleic and amino acid sequences. The 3'-terminal 1,294 nucleotides (nt) were sequenced encompassing the $\mathrm{C}$-terminal part of NIb (the putative polymerase), the entire $\mathrm{CP}$, and the $3^{\prime}$ nontranslated region ( $3^{\prime} \mathrm{NTR}$ ) of ZeMV (Fig. 1) (deposited with GenBank under accession number AF228693). The 3'NTR region of ZeMV had $235 \mathrm{nt}$. The cleavage site between the NIb and CP was determined by comparison with those of other potyviruses (13). The four amino acids preceding the cleavage site were VFHQ for SCMV, VEHQ for JGMV, VRHQ for JGMV, VYHQ for MDMV, and VVHQ for ZeMV. The typical motifs MVWCIENG and QMKAAA of potyviruses in the CP region (30) were present in ZeMV. A DVG rather than a DAG motif was present at amino acids 53 to 55 (amino acids 5 to 7 of the $\mathrm{CP}$ ). A single nucleotide difference was observed in the clones sequenced. In one clone, $\mathrm{C}$ was substituted for $\mathrm{T}$ at nucleotide 762 ; however, this was of no consequence at the amino acid level, because TAT $=$ TAC $=$ Y. A second ambiguity occurred at position 964: two clones had an AAT triplet (asparagine $\mathrm{N}$ ) and one a GAT triplet (aspartic acid D) corresponding to amino acid residue 322.

The amino acid sequence determined by TOFMS confirmed $\mathrm{Y}$ at nucleotide 762, as expected. The presence of a mixture of $\mathrm{N}$ and $\mathrm{D}$ at the other location would be indicated by an anomalous isotopic distribution in the proteolytic fragment(s) containing this residue. The insert in Figure 2 shows the isotopic distribution for the fragment MFGLDGN(D)VGESQENTER corresponding to the amino acid residues 316 to 332 (268 to 284 in the CP). The measured mass of $1,882.82 \mathrm{Da}$ is consistent with the mass calculated

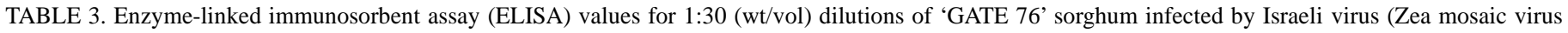

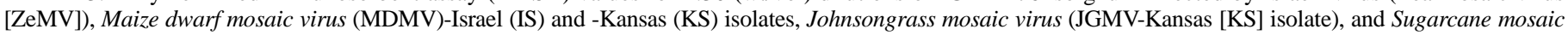
virus strain MDB (MDB, Kansas isolate) tested against antisera made to ZeMV, JGMV (Kansas source), MDMV (PVAS 55), and SCMV-MDB (MDB, Ohio source)

\begin{tabular}{|c|c|c|c|c|c|c|c|c|c|c|c|c|}
\hline \multirow[b]{2}{*}{ Antiserum } & \multirow{2}{*}{$\begin{array}{l}\text { Antiserum } \\
\text { dilution }\end{array}$} & \multicolumn{11}{|c|}{ Virus isolate and control } \\
\hline & & ZeMV & $\mathrm{DHV}^{\mathrm{z}}$ & MDMV-IS & DHV & MDMV-KS & DHV & JGMV-KS & DHV & MDB & DHV & Healthy sorghum \\
\hline ZeMV & $1: 100$ & 1.429 & 5.4 & 0.305 & 1.2 & 0.324 & 1.2 & 0.328 & 1.2 & 0.926 & 3.5 & 0.265 \\
\hline ZeMV & $1: 200$ & 1.232 & 6.6 & 0.182 & 1.0 & 0.254 & 1.4 & 0.217 & 1.2 & 0.615 & 3.3 & 0.186 \\
\hline ZeMV & $1: 400$ & 0.930 & 7.6 & 0.112 & 0.9 & 0.168 & 1.4 & 0.147 & 1.2 & 0.387 & 3.1 & 0.123 \\
\hline ZeMV & $1: 800$ & 0.601 & 7.7 & 0.072 & 0.9 & 0.099 & 1.3 & 0.018 & 0.2 & 0.221 & 2.8 & 0.078 \\
\hline ZeMV & $1: 1,600$ & 0.346 & 8.4 & 0.033 & 0.8 & 0.046 & 1.1 & 0.034 & 0.8 & 0.106 & 2.6 & 0.041 \\
\hline JGMV-KS & $1: 1,600$ & 0.238 & 2.2 & 0.125 & 1.2 & 0.218 & 2.1 & 0.929 & 8.8 & 0.214 & 2.0 & 0.106 \\
\hline MDB & $1: 400$ & 0.084 & 4.9 & 0.000 & 0.0 & 0.033 & 1.9 & 0.017 & 1.0 & 0.230 & 13.5 & 0.017 \\
\hline PVAS 55 & $1: 1,600$ & 0.088 & 0.8 & 0.288 & 22.2 & 0.414 & 31.8 & 0.013 & 1.0 & 0.074 & 5.7 & 0.013 \\
\hline
\end{tabular}

y Antisera dilutions were prepared from $1-\mathrm{mg} / \mathrm{ml}$ stock solutions.

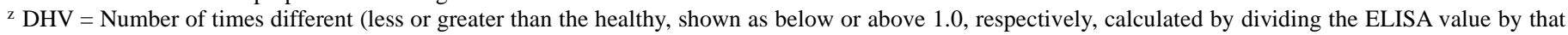
of the healthy control) than the equivalent healthy control value for an ELISA value for a respective antiserum. Values presented are representative of two additional experiments. 


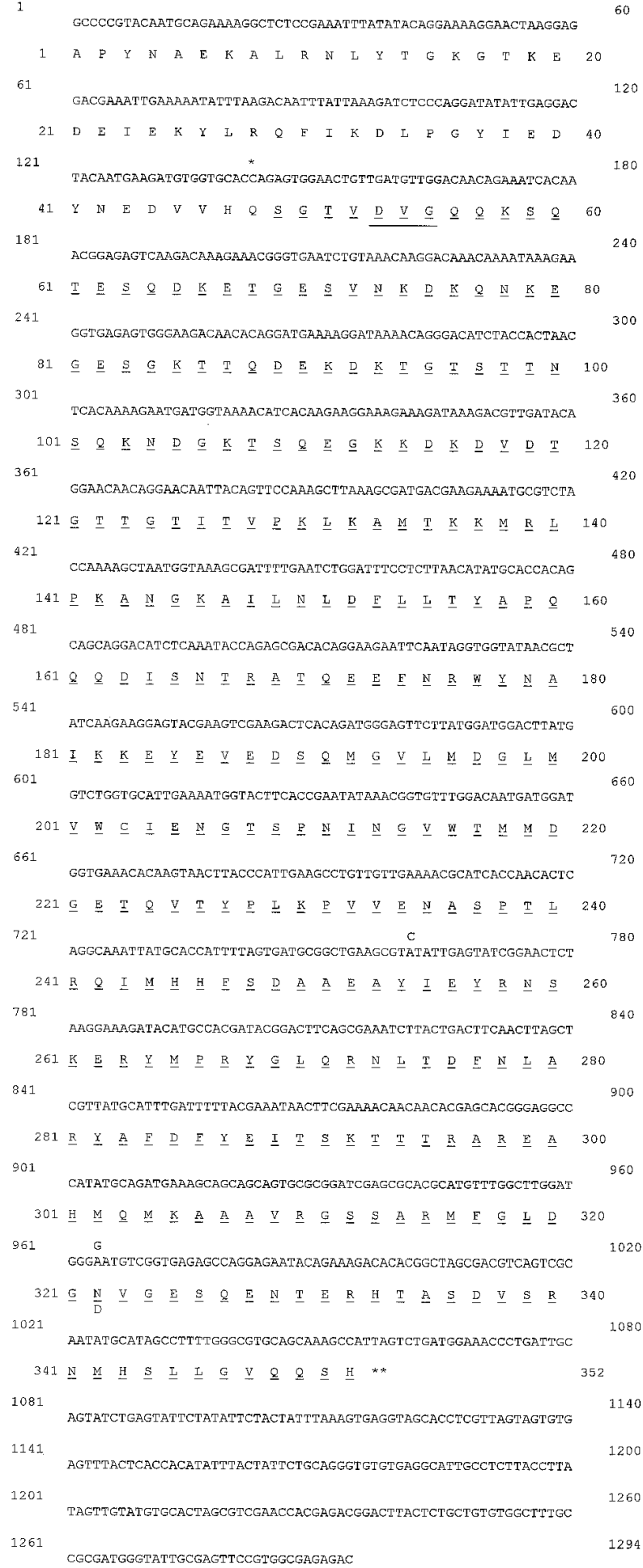

Fig. 1. Nucleotide sequence of Zea mosaic virus (ZeMV) (numbered from the $5^{\prime}$ end of the viral RNA strand) and its deduced amino acid sequence. The absolute amino acid sequence, determined by time-of-flight mass spectrometry (TOFMS) using matrix-assisted laser desorption/ionization, electrospray/TOF and tandem mass spectrometry procedures of ZeMV, is represented by the dashed line beneath the deduced amino acid sequence and indicates consensus with the deduced amino acid sequence. The solid line beneath amino acids 53,54 , and 55 (DVG) identifies the location of the DAG motif usually found in aphid-transmissible viruses. The base $\mathrm{C}$ at position 762 and the base $\mathrm{G}$ and corresponding amino acid D at position 964 indicate differences associated with the different clones sequenced. $*=$ Termination codon, and $* *=$ location of predicted cleavage site between nuclear inclusion a (NIa) and the coat protein. Numbering: outer columns of numbers refer to the nucleotide sequence and the inner columns of numbers refer to the amino acid sequence. for this fragment with $\mathrm{N}$ at residue 322 , and the isotopic distribution is consistent with a zero contribution from $\mathrm{D}$; we estimate its maximum possible intensity as a few percent.

A feature of protein sequencing not provided by the nucleic acid sequence is detection of posttranslational modifications of the protein. In this case, only one anomaly was observed; no ions were detected corresponding to the calculated masses of the N-terminal proteolytic fragments; residues 1 to 10 of the $\mathrm{CP}$ for trypsin and the proteases Lys-C and Arg-C (1,018.52 Da), and residues 1 to 14 of the CP for the protease Glu-C (1,463.69 Da). However, clear signals were observed for masses 1,060.52 and 1,505.68 Da, which were $42 \mathrm{Da}$ greater than the calculated values, indicating acetylation at the N-terminus.

Paired comparisons in the $3^{\prime} \mathrm{NTR}$ or in the CP gene among poaceae-infecting potyviruses (including ZeMV); PVY, the type member of the genus Potyvirus; and RGMV, the type member of the genus Rymovirus, are given in Table 2 (numbers above the diagonal). Only a few strains of each potyvirus from the family Poaceae were chosen to cover the geographical distribution. For SrMV, we present only the results for SrMV-SCH, because the strains of SrMV are very close to each other and all have been described in the United States (55). In the $3^{\prime} \mathrm{NTR}$, nucleotide sequence identities among ZeMV, SCMV, MDMV, and SrMV were approximately $60 \%$ (ranging from 59 to $66 \%$ ). The sequence identities among ZeMV, JGMV, and PVY averaged approximately $40 \%$ (ranging from 35 to $46 \%$ ).

The percentages of similarities in amino acid sequences among viruses compared with ZeMV are presented in Table 2 (numbers below the diagonal). The upper number below the diagonal represents whole CP comparison and the lower number compares only amino acids of the core of the CP. The amino acid similarities of the whole CP of ZeMV compared with different strains of SCMV, MDMV, and SrMV ranged between 69 and 75\%, but the similarities averaged approximately $85 \%$ when only the core of the protein was considered. For JGMV, similarities were $64 \%$ for the entire CP and $75 \%$ for the core. These values are very similar to those for PVY (68 and 74\%), but similarities were smaller with RGMV.

Figure 3 shows a phylogenetic tree illustrating the position of ZeMV among the members of the family Potyviridae and in relation to RGMV. ZeMV did not group with any of the viruses compared in this analysis.

\section{DISCUSSION}

Serological analysis indicated that ZeMV was not related to MDMV, JGMV, and SrMV (Table 3), but the weak reaction to SCMV-MDB antiserum indicated that it might be an isolate of SCMV-MDB. However, this possibility was not supported by ZeMV's infection of johnsongrass, which is not a host for SCMVMDB $(27,44)$. In spite of its infection of johnsongrass, ZeMV evidently shares epitopes with SCMV-MDB rather than with MDMV and JGMV, both of which also infect johnsongrass $(6,29)$. Weak

TABLE 4. Phenotypic ${ }^{y}$ response of different sorghum lines to infection by Maize dwarf mosaic virus (MDMV, Kansas isolate), Sugarcane mosaic virus strain MDMV-B (SCMV-MDB, Kansas isolate), Johnsongrass mosaic virus (JGMV, Kansas isolate), Sorghum mosaic virus (SrMV, PV 323 isolate), and the Israeli virus (Zea mosaic virus [ZeMV])

\begin{tabular}{lccccc}
\hline & \multicolumn{5}{c}{ Virus isolate } \\
\cline { 2 - 6 } Sorghum line & MDMV & SCMV-MDB & JGMV & SrMV & ZeMV \\
\hline KS 6R & $\underline{\mathrm{M}}^{\mathrm{z}}$ & $\mathrm{N}$ & $\underline{\mathrm{M}}$ & $\mathrm{N}$ & $\mathrm{N}$ \\
KS 35A & $\mathrm{N}$ & $\underline{\mathrm{M}}$ & $\underline{\mathrm{M}}$ & $\mathrm{N}$ & $\mathrm{N}$ \\
KS 36A & $\mathrm{N}$ & $\underline{\mathrm{M}}$ & $\underline{\mathrm{M}}$ & $\underline{\mathrm{N}}$ & $\mathrm{N}$ \\
KS 53R & $\mathrm{M}$ & $\mathrm{M}$ & $\mathrm{M}$ &
\end{tabular}

${ }^{y}$ Plants held at $29^{\circ} \mathrm{C}$ for 2 weeks following inoculation and then placed at $18^{\circ} \mathrm{C}$ for 5 days, after which symptoms were recorded.

${ }^{\mathrm{z}}$ Underlined letters indicate reaction of cultivar different from that of ZeMV ( $\mathrm{M}=$ mosaic symptoms and $\mathrm{N}=$ necrosis $)$. 
cross-reactivities have been reported with heterologous antisera against other potyviruses (54). Similar results were observed using antiserum made to purified ZeMV (using virus passaged through johnsongrass), which is noteworthy because SCMV-MDB has not been reported to occur in Israel (R. Salomon, personal communication). In Israel, antiserum prepared against ZeMV reacted specifically to ZeMV and not to the Israeli MDMV isolate (8). In other experiments, we also demonstrated that ZeMV was negative in ELISA using antiserum made against the $\mathrm{H}$ and $\mathrm{I}$ isolates of SrMV. This was not unexpected, because the ZeMV antiserum was negative in ELISA to SrMV.

In SDS-PAGE, the capsid of ZeMV migrated to a position between those of MDMV and SCMV-MDB capsids and similar to the position of JGMV capsid, which may account for it being considered tentatively as a variant of JGMV (8). The average relative mass of ZeMV in three SDS-PAGE experiments was $36,776 \mathrm{Da}$, $2,562 \mathrm{Da}$ larger than the $34,214 \mathrm{kDa}$ determined by the more sensitive TOFMS analysis. The values obtained for the other viruses were 34,836 Da (MDMV-IS), 35,570 Da (MDMV-KS), 37,541 Da (SCMV-MDB-KS), 35,237 Da (JGMV-KS), and 38,191 Da (SrMV). These values are consistent with those previously reported: 36,777 (26) and 37,500 Da (19) for MDMV; 36,313 (26) and 37,300 to $39,700 \mathrm{Da}$ (19) for SCMV-MDB; 37,888 (26), 35,100 (30), and $35,000 \mathrm{Da}$ (31) for JGMV; and 37,400 to 39,100 Da for isolates $\mathrm{H}$ and M of SrMV (19). These previous reports indicate differences associated with isolates. Therefore, the slight differences we determined for the masses of the different capsids compared with those of other studies probably reflect differences in isolates and experimental variation associated with SDS-PAGE. Thus, SDS-PAGE provided a relative reference concerning the electrophoretic mobility of ZeMV compared with isolates MDMV, SCMV-MDB, JGMV, and SrMV, but did not readily separate virus species.

Infection of 19 sorghum lines by MDMV, SCMV-MDB, JGMV, SrMV, and ZeMV showed that ZeMV induced more necrosis than all viruses except for the PV 323 isolate of SrMV. This supported previous observations in Israel, in which this isolate was reported to be more aggressive than MDMV in sorghum than in maize (8). Infection of KS 6R by ZeMV induced necrosis, which differenti- ated it from MDMV and JGMV, but not from SCMV-MDB and SrMV. Infection of KS 35A by ZeMV again caused necrosis, which separated it from SCMV-MDB and JGMV, and the same results occurred for KS 36A. Infection of KS 35A by ZeMV resulted in only mosaic symptoms, which differed from SrMV, but not from the other viruses. Thus, these sorghum lines provided a limited separation of isolates.

The amino acid sequence of ZeMV (Fig. 1) showed that the putative cleavage site between the $\mathrm{NIb}$ and $\mathrm{CP}$ sequences was similar, but not identical, to that of other potyviruses (13). The four amino acids preceding the cleavage site are VFHQ for SCMV, VEHQ and VRHQ for JGMV, VYHQ for MDMV, and VVHQ for ZeMV. The typical motifs MVWCIENG and QMKAAA of potyviruses (38) in the CP region were also present in ZeMV. DVG rather than a DAG motif present at amino acids 53 to 55 , which are four amino acids from the $\mathrm{N}$-termini of the $\mathrm{CP}$, differs from many other aphid-transmitted potyviruses, although the aphid-vectored potyvirus, Passionfruit woodiness virus, also has the DVG rather than the DAG motif (45). The DAG motif is considered to play a crucial role in aphid transmission (35). However, Atreya et al. (5) found that substitution of DAG for DVG in the N-terminal part of the coat protein gene of Tobacco vein mottling virus decreased aphid transmission but did not abolish it. No sequence ambiguity was demonstrated by either nucleic acid sequencing or TOFMS, as might be expected if the viral population coexisted with virions having both the DAG or DVG motifs. Once the DVG motif in ZeMV was confirmed by both techniques at two locations, ZeMV was compared with MDMV for efficiency of transmission in Israel. Significantly fewer sorghum plants (average of $40 \%$ for MDMV versus $15 \%$ for ZeMV in three experiments) were infected using viruliferous Myzus persicae (Sulzer).

Rybicki and Shukla (38) emphasized the key role of sequence analysis in potyvirus taxonomy. The $3^{\prime} \mathrm{NTR}$ is useful for discriminating between strains of a given virus or different viruses $(15,33)$. $\mathrm{CP}$ sequences are useful to discriminate and to reconstruct phylogenetic relationships among potyviruses (38). The 3'NTR of ZeMV is $235 \mathrm{nt}$ long, which is the same as those of MDMV-JIL (GenEMBL U07216) and SrMV-SCH-TX (55), and only 1 nt longer

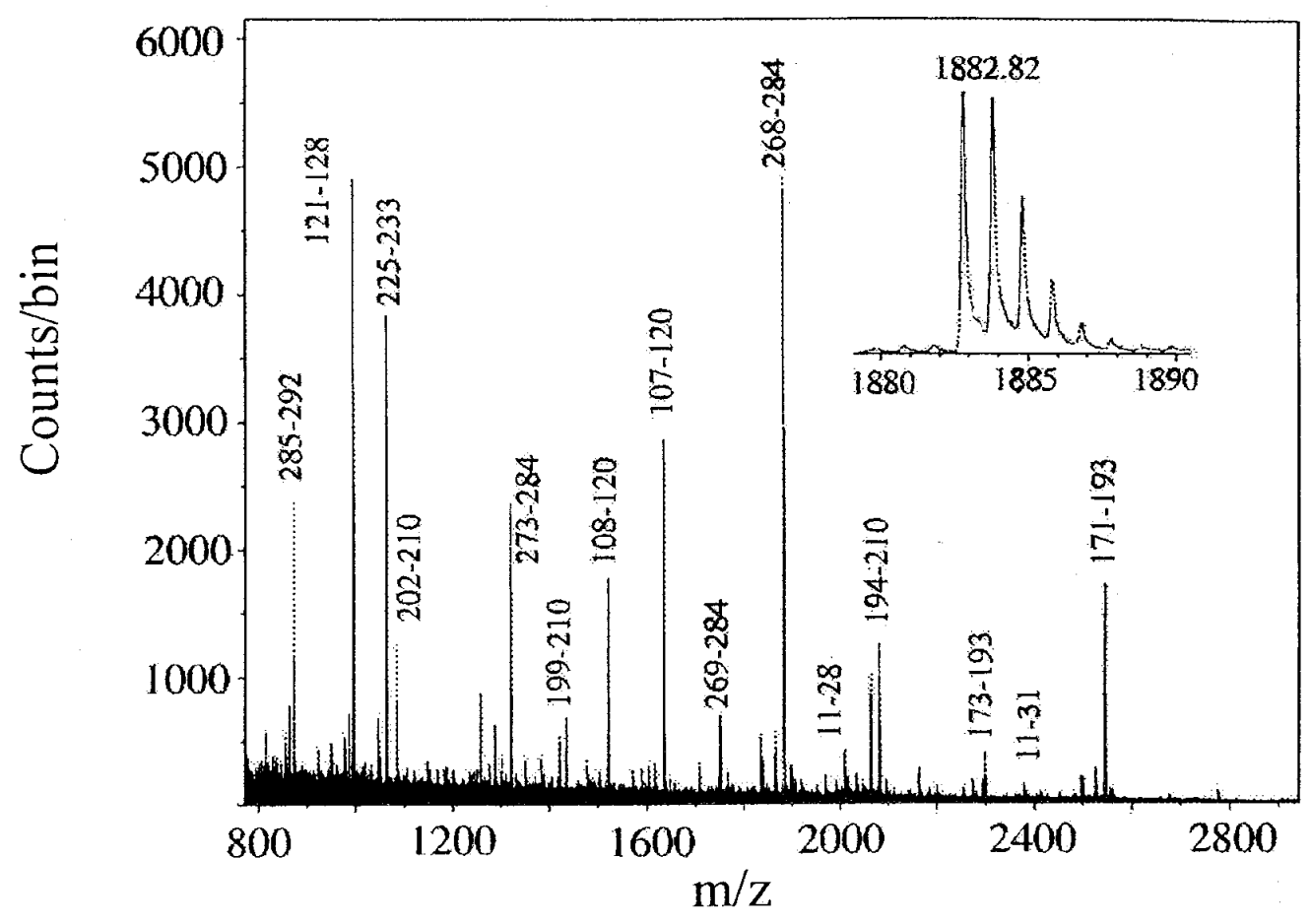

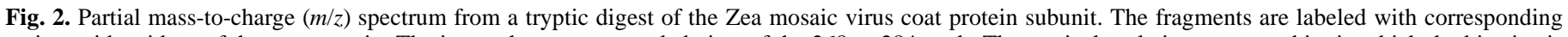

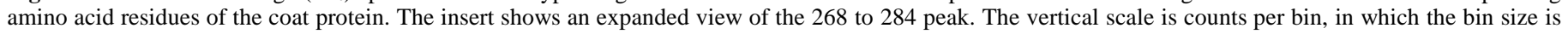
in 0.625-nanosecond intervals. 


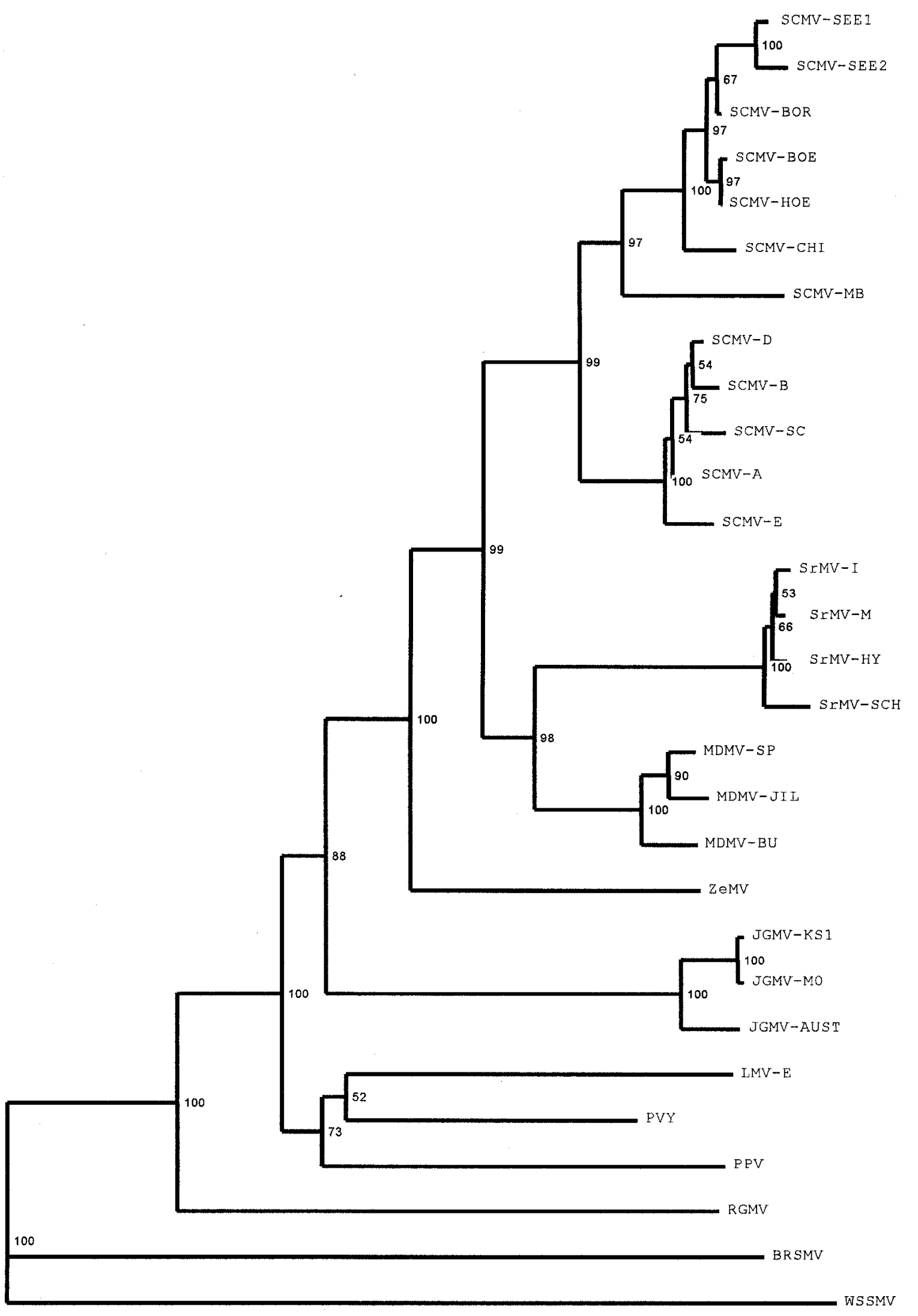

0.1

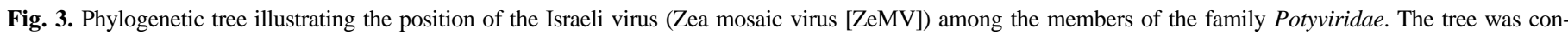

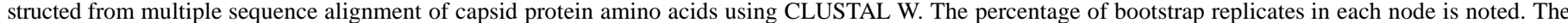
scale bar represents, for the horizontal branch lengths, a genetic distance of 0.1 . Sequences used for the alignments were obtained from the GenBank/EMBL. 
than the $3^{\prime}$ NTR of SCMV-MDB (14), but clearly different from the 473-nt 3'NTR of JGMV-AUST (17). In the 3'NTR, the nucleotide sequence identity among ZeMV, SCMV, MDMV, and SrMV was approximately $60 \%$, and that among ZeMV, JGMV, PVY, and RGMV was approximately $40 \%$. The $60 \%$ value is clearly intermediate between those obtained for strains of a given potyvirus (15), e.g., above $88 \%$ for the viruses considered in this study, and those obtained for distinct viruses, which range between 39 and $53 \%$. Thus, nucleotide comparisons in the $3^{\prime} \mathrm{NTR}$ clearly showed that ZeMV is not a strain of MDMV, SCMV, SrMV, or JGMV.

Figure 3 shows a phylogenetic tree with bootstrap analysis obtained from multiple alignment of $\mathrm{CP}$ amino acid segments with Clustal W. Other phylogenetic reconstructions using PAUP (data not shown) based on CP amino acid sequences or CP nucleic acid sequences placed ZeMV in the same position respective to the other potyviruses. Its nucleic acid and amino acid sequences in multiple comparison analysis with corresponding sequences of poaceae-infecting potyviruses did not cluster with any of the four previously described viruses and showed that ZeMV is equidistant from SCMV, MDMV, and SrMV, and more distantly related to JGMV.

Our results lead to the conclusion that ZeMV is unambiguously a new potyvirus infecting hosts in the family Poaceae. It has a slight cross-reaction to SCMV-MDB antiserum, but not to antisera of MDMV, JGMV, and SrMV; its nucleic acid and amino acid sequences do not cluster with any of the four previously described potyviruses of the family Poaceae, and it is phylogenetically equidistant from SCMV, MDMV, and SrMV and closer to this group than to JGMV. We propose the name Zea mosaic virus (ZeMV-IS) for this virus isolated from maize in Israel. Because of the demonstrated virulence of ZeMV in sorghum, its mild effect on sweet corn (8), and its unique character in relation to the other poaceaeinfecting potyviruses, further work should be considered to determine effects of infection by ZeMV on expanded numbers of sorghum germ plasm and to determine a more detailed host range.

\section{ACKNOWLEDGMENTS}

Contribution no. 00-75-J from the Kansas Agricultural Experiment Station, Manhattan 66506. Research was supported, in part, by a grant from the Kansas Sorghum Commission. We thank J. Ackerman for his valuable assistance in virus purification, electrophoresis, enzyme-linked immunosorbent assay, western blotting, and other phases of this investigation.

\section{LITERATURE CITED}

1. Abbott, E. V. 1961. A new strain of sugarcane mosaic virus. (Abstr.) Phytopathology 51:642.

2. Achon, M. A., Medina, V., Shanks, M., Markham, P. G., and Lomonossoff, G. P. 1994. Characterization of a maize-infecting potyvirus from Spain. Eur. J. Plant Pathol. 100:157-165.

3. American Type Culture Collection. 1986. Catalog and Registry of the Plant Viruses. ATCC, Rockville, MD.

4. Antignus, Y. 1987. Comparative study of two maize dwarf mosaic virus strains infecting corn and johnsongrass in Israel. Plant Dis. 71:687-691.

5. Atreya, P. L., Lopez-Moya, J. J., Chu, M., Atreya, C. D., and Pirone, T. P. 1995. Mutational analysis of the coat protein N-terminal amino acids involved in potyvirus transmission by aphids. J. Gen. Virol. 76:265-270.

6. Bancroft, J. B., Ullstrup, A. J., Messieha, M., Bracker, C. E., and Snazelle, T. E. 1966. Some biological and physical properties of a midwestern isolate of maize dwarf mosaic virus. Phytopathology 56:474-478.

7. Barnett, O. W. 1992. A summary of potyvirus taxonomy and definitions. Arch. Virol. 5(suppl.):435-444.

8. Bar-Zur, A., and Salomon, R. 1995. Partial resistance of sugary enhancer sweet corn genotypes to two isolates of the sugarcane mosaic subgroup of potyviruses. Plant Dis. 79:243-246.

9. Bollig, D. M., and Edelstein, S. J. 1991. Immunoblotting. Pages 181-208 in: Protein Methods. Wiley-Liss, New York.

10. Chachulska, A. M., Fakhfakh, H., Robaglia, C., Granier, F., Zagorski, W., and Vilaine, F. 1997. Synthesis of full-length potyvirus cDNA copies suitable for the analysis of genome polymorphism. J. Virol. Methods 67: 189-197.

11. Chernushevich, I. V., Ens, W., and Standing, K. G. 1999. Orthogonal injection time-of-flight mass spectrometry for analysis of biomolecules.
Anal. Chem. 71:452A-461A.

12. Devereux, J., Haeberli, P., and Smithies, O. 1984. A comprehensive set of sequence analysis programs for the VAX. Nucleic Acids Res. 12:387-395.

13. Dinant, S., Lot, H., Albouy, J., Kuziak, C., Meyer, M., and AstierManifacier, S. 1991. Nucleotide sequence of the $3^{\prime}$ terminal region of lettuce mosaic potyvirus RNA shows a Gln\Val dipeptide at the cleavage site between the polymerase and the coat protein. Arch. Virol. 116:235-252.

14. Frenkel, M. J., Jilka, J. M., McKern, M., Strike, P. M., Clark, J. M., Shukla, D. D., and Ward, C. W. 1991. Unexpected sequence diversity in the amino-terminal ends of the coat proteins of strains of sugarcane mosaic virus. J. Gen. Virol. 72:237-242.

15. Frenkel, M. J., Ward, C. W., and Shukla, D. D. 1989. The use of 3' noncoding nucleotide sequences in the taxonomy of potyviruses: Application to watermelon mosaic virus 2 and soybean mosaic virus. J. Gen. Virol. 70:2775-2783.

16. Gotz, R., and Maiss, E. 1995. The complete nucleotide sequence and genome organization of the mite-transmitted brome streak mosaic rymovirus in comparison to those of potyviruses. J. Gen. Virol. 76:2035-2042.

17. Gough, K. H., and Shukla, D. D. 1993. Nucleotide sequence of johnsongrass mosaic virus genomic RNA. Intervirology 36:181-192.

18. Hollings, M., and Brunt, A. 1981. Potyvirus Group. Descriptions of Plant Viruses No. 245. Commonw. Mycol. Inst./Assoc. Appl. Biol., Kew, Surrey, England.

19. Jensen, S. G., Long-Davidson, B., and Seip, L. 1986. Size variation among proteins induced by sugarcane mosaic viruses in plant tissue. Phytopathology 76:528-532.

20. Klein, M., Harpaz, I., Greenberger, A., and Sela, I. 1973. A mosaic virus disease of maize and sorghum in Israel. Plant Dis. Rep. 57:125-128.

21. Koike, H., and Gillaspie, Jr., A. G. 1976. Strain M, a new strain of sugarcane mosaic virus. Plant Dis. Rep. 60:50-54.

22. Kong, P., and Steinbiss, H. H. 1998. Complete nucleotide sequence and analysis of the putative polyprotein of maize dwarf mosaic virus genome RNA (Bulgarian isolate). Arch. Virol. 143:1791-1799.

23. Laemmli, U. K. 1970. Cleavage of structural proteins during the assembly of head of bacteriophage T4. Nature 227:680-685.

24. Lain, S., Riechmann, J. L., Mendez, E., and Garcia, J. A. 1988. Nucleotide sequence of the $3^{\prime}$ terminal region of plum pox potyvirus RNA. Virus Res. 10:325-342.

25. Lane, L. C. 1986. Propagation and purification of RNA plant viruses. Methods Enzymol. 118:687-696.

26. Langham, M. A., and Toler, R. W. 1985. A molecular weight analysis of the capsid proteins from maize dwarf mosaic virus strains. (Abstr.) Phytopathology 75:1357.

27. MacKenzie, D. R., Wernham, C. C., and Ford, R. E. 1966. Differences in maize dwarf mosaic virus isolates of the northeastern United States. Plant Dis. Rep. 50:814-818.

28. Matthews, R. E. F. 1982. Classification and nomenclature of viruses. Fourth Report of the International Committee on Classification of Viruses. Intervirology 17:1-99.

29. McDaniel, L. L., and Gordon, D. T. 1985. Identification of a new strain of maize dwarf mosaic virus. Plant Dis. 69:602-607.

30. McDaniel, L. L., and Gordon, D. T. 1989. Characterization of the oatinfecting strain of maize dwarf mosaic virus. Phytopathology 79:113-120.

31. McKern, N. M., Whittaker, L. A., Strike, P. M., Ford, R. E., Jensen, S. G., and Shukla, D. D. 1990. Coat protein properties indicate that maize dwarf mosaic virus-KS1 is a strain of johnsongrass mosaic virus. Phytopathology 80:907-912.

32. Oertel, U., Schubert, J., and Fuchs, E. 1997. Sequence comparison of the $3^{\prime}$ part of the RNA of four German isolates of sugarcane mosaic potyvirus (SCMV). Arch. Virol. 142:675-687.

33. Pappu, S. S., Brand, R., Pappu, H. R., Rybicki, E. P., Gough, K. H., Frenkel, M. J., and Niblett, C. L. 1993. A polymerase chain reaction method adapted for selective amplification and cloning of $3^{\prime}$ sequences of potyviral genomes: Application to dasheen mosaic virus. J. Virol. Methods 41:9-20.

34. Pirone, T. P. 1972. Sugarcane mosaic virus. Descriptions of Plant Viruses No. 88. Commonw. Mycol. Inst./Assoc. Appl. Biol., Kew, Surrey, England.

35. Pirone, T. P., and Blanc, S. 1996. Helper-dependent vector transmission of plant viruses. Annu. Rev. Phytopathol. 34:227-247.

36. Revers, F., Yang, S. J., Walter, J., Souche, S., Lot, H., Le Gall, O., Candresse, T., and Dunez, J. 1997. Comparison of the complete nucleotide sequences of two isolates of lettuce mosaic virus differing in their biological properties. Virus Res. 47:167-177.

37. Robaglia, C., Durand-Tardif, M., Tronchet, M., Boudazin, G., AstierManifacier, S., and Casse-Delbart, F. 1989. Nucleotide sequence of potato virus Y (N strain) genomic RNA. J. Gen. Virol. 70:935-947.

38. Rybicki, E. P., and Shukla, D. D. 1992. Coat protein phylogeny and systematics of potyviruses. Arch. Virol. 5(suppl.):139-170.

39. Sai, J., Kang, L., Huang, Z., Shi, C., Thian, B., and Xie, Y. 1994. Nu- 
cleotide sequence of maize dwarf mosaic virus capsid protein gene and its expression in E. coli. Sci. China 38:313-319.

40. Schubert, J., Rabenstein, F., and Proll, E. 1995. Sequence of the 3' part of the RNA of ryegrass mosaic virus, a potyvirus. Agronomie 15:447-452.

41. Seifers, D. L., and Caceres, J. 1988. Titer variation in infected sorghum differing in resistance to maize dwarf mosaic virus strain-B. Phytopathology 78:208-212.

42. Seifers, D. L., Harvey, T. L., and Bowden, R. L. 1995. Occurrence and symptom expression of American wheat striate mosaic virus in wheat in Kansas. Plant Dis. 79:853-858.

43. Seifers, D. L., Harvey, T. L., Kofoid, K. D., and Stegmeier, W. D. 1996. Natural infection of pearl millet and sorghum by wheat streak mosaic virus in Kansas. Plant Dis. 80:179-185.

44. Shepherd, R. J. 1965. Properties of a mosaic virus of corn and johnson grass and its relation to the sugarcane mosaic virus. Phytopathology 55: 1250-1256.

45. Shukla, D. D., McKern, N. M., and Ward, C. W. 1988. Coat protein of potyviruses. 5. Symptomology, serology, and coat protein sequences of three strains of passionfruit woodiness virus. Arch. Virol. 102:221-232.

46. Shukla, D. D., and Teakle, D. S. 1989. Johnsongrass mosaic virus. Descriptions of Plant Viruses No. 340. Commonw. Mycol. Inst./Assoc. Appl. Biol., Kew, Surrey, England.

47. Shukla, D. D., Tosic, M., Jilka, J., Ford, R. E., Toler, R. W., and Langham, M. A. C. 1989. Taxonomy of potyviruses infecting maize, sorghum, and sugarcane in Australia and the United States as determined by reactivities of polyclonal antibodies directed towards virus-specific N-termini of coat proteins. Phytopathology 79:223-229.

48. Shukla, D. D., and Ward, C. W. 1989. Identification and classification of potyviruses on the basis of coat protein sequence data and serology. Arch. Virol. 106:171-200.

49. Sohn, A., Schenk, P., Signoret, P., Schmitz, G., Schell, J., and Steinbiß, H. H. 1995. Sequence analysis of the 3'-terminal half of RNA1 of wheat spindle streak mosaic virus. Arch. Virol. 135:279-292.

50. Tang, X., Beavis, R., Ens, W., Lafortune, F., Schueler, B., and Standing, K. G. 1988. A secondary ion time-of-flight mass spectrometer with an ion mirror. Int. J. Mass Spectrom. Ion Processes 85:43-67.

51. Thompson, J. D., Higgins, D. G., and Gibson, T. J. 1994. Clustal W: Improving the sensitivity of progressive multiple sequence alignment through sequence weighting, position-specific gap penalties and weight matrix choice. Nucleic Acids Res. 22:4673-4680.

52. Tippett, R. L., and Abbott, E. V. 1968. A new strain of sugarcane mosaic virus in Louisiana. Plant Dis. Rep. 52:449-451.

53. Verentchikov, A., Ens, W., and Standing, K. G. 1994. Reflecting time-offlight mass spectrometer with an electrospray ion source and orthogonal extraction. Anal. Chem. 66:126-133.

54. Ward, C. W., and Shukla, D. D. 1991. Taxonomy of potyviruses: Current problems and some solutions. Intervirology 32:269-296.

55. Yang, Z. N., and Mirkov, T. E. 1997. Sequence and relationships of sugarcane mosaic and sorghum mosaic virus strains and development of RTPCR-based RFLPs for strain discrimination. Phytopathology 87:932-939. 